Available online at: http://openjournal.masda.ac.id/index.php/edumasda

Edu Masda Journal

ISSN (Print) 2597-4572 ISSN (Online) 2715-5269

\title{
LITERATURE REVIEW UJI EVALUASI SEDIAAN KRIM
}

\author{
Neneng Sri Purwaningsih ${ }^{1 *}$, Siti Novy Romlah ${ }^{2}$, Ayu Choirunnisa ${ }^{3}$ \\ ${ }^{1,3}$ STIKes Kharisma Persada, J1. Pajajaran No 1, Tangerang Selatan 15417, Indonesia \\ ${ }^{2}$ STIKes Widya Dharma Husada Tangerang, J1. Pajajaran No 1, Tangerang Selatan 15417, Indonesia
}

\begin{tabular}{|c|c|}
\hline ARTICLE INFORMATION & $A B S T R A C T$ \\
\hline $\begin{array}{l}\text { *Corresponding Author } \\
\text { Neneng Sri Purwaningsih } \\
\text { E-mail : neneng@masda.ac.id }\end{array}$ & $\begin{array}{l}\text { The format of preparation cosmetic in a cream form is still } \\
\text { popular in Indonesia, especially for the women. Because its } \\
\text { easier to applied, and more comfortable. Literature review of } \\
\text { evaluation cream preparation test is to compare the results of } \\
\text { cream evaluation preparation from the previous researches in }\end{array}$ \\
\hline $\begin{array}{l}\text { Keywords: } \\
\text { Evaluation of cream preparation } \\
\text { Organoleptic test } \\
\text { pH test } \\
\text { Homogenity test } \\
\text { Type cream test }\end{array}$ & $\begin{array}{l}\text { conditions. The general purpose of this research is to know the } \\
\text { results of Literature review of evaluation cream preparation test } \\
\text { from several journals. Method This research is qualitative } \\
\text { research which is Library research Cream evaluation } \\
\text { preparation is a Parameters that have been established to } \\
\text { determine the stability of cream preparation including } \\
\text { organoleptic test, pH test, homogeneity test, type cream test, } \\
\text { viscosity test, and scattering test. From the result of organoleptic } \\
\text { test, pH test, viscosity test and scattering test review have the } \\
\text { results partial test standards, and some doesn't. this is due to the } \\
\text { temperature factor, excessive extract concentration and chemical } \\
\text { reaction at the time of storage is accelerated. Whereas at the } \\
\text { results of homogeneity test have a quite good homogeneity, and } \\
\text { in a type cream test has A/M and M/A type cream. }\end{array}$ \\
\hline $\begin{array}{l}\text { Kata Kunci: } \\
\text { Evaluasi sediaan krim } \\
\text { Uji organoleptik } \\
\text { Uji pH } \\
\text { Uji homogenitas } \\
\text { Uji tipe krim }\end{array}$ & $\begin{array}{l}\text { Bentuk sediaan kosmetik berupa krim sampai saat ini } \\
\text { masih banyak digemari oleh masyarakat Indonesia khususnya } \\
\text { kaum wanita karena lebih mudah diaplikasikan, lebih nyaman } \\
\text { digunakan. Literatur Review Uji Evaluasi Sediaan Krim adalah } \\
\text { untuk membandingkan hasil evaluasi sediaan krim dari } \\
\text { penelitian-penelitian sebelumnya agar mendapatkan hasil uji } \\
\text { yang terbaik dan sesuai dengan ketentuan yang telah ditetapkan. } \\
\text { Tujuan Umum dari penelitian ini adalah untuk mengetahui hasil } \\
\text { Literatur Review uji evaluasi sediaan krim dari berberapa jurnal. } \\
\text { Metode Penelitian ini adalah penelitian kualitatif yang bersifat } \\
\text { studi pustaka (library research) yang menggunakan buku-buku } \\
\text { dan literatur-literatur lainnya sebagai objek yang utama. Evaluasi } \\
\text { sediaan krim adalah parameter yang telah ditetapkan untuk } \\
\text { mengetahui kestabilan sediaan krim diantaranya uji organoleptik, } \\
\text { uji homogenitas, uji pH, uji tipe krim, uji viskositas, dan uji } \\
\text { Daya sebar. Hasil review uji organoleptik, pH, viksositas dan } \\
\text { daya sebar memiliki hasil sebagian memenuhi standar uji, dan } \\
\text { sebagian tidak memenuhi standar uji yang telah ditetapkan. Hal } \\
\text { ini dikarenakan faktor suhu, konsentrasi ekstrak yang berlebih } \\
\text { serta reaksi kimia pada saat penyimpanan dipercepat. Sedangkan } \\
\text { pada hasil uji homogenitas secara keseluruhan jurnal yang diuji } \\
\text { memiliki homogenitas yang cukup baik, serta uji tipe krim yaitu } \\
\text { memiliki tipe krim A/M dan M/A }\end{array}$ \\
\hline
\end{tabular}




\section{PENDAHULUAN}

Bentuk sediaan kosmetik cukup beragam, sediaan farmasi dalam bentuk krim masih banyak digunakan di Indonesia karena krim memiliki keuntungan sediaan antara lain lebih mudah diaplikasikan, lebih nyaman digunakan pada kulit serta tidak lengket dan mudah dicuci dengan air (Sharon dkk, 2013). Krim adalah bentuk sediaan setengah padat mengandung satu atau lebih bahan obat terlarut atau terdispersi dalam bahan dasar yang sesuai. Biasanya sebagai emulsi air dalam minyak atau minyak dalam air dan lebih ditujukan untuk penggunaan kosmetika dan estetika (FI edisi V, 2014). Keuntungan dari krim mudah terabsorsi pada kulit sehingga banyak industri farmasi di Indonesia memilih memproduksi krim sebagai bentuk sediaan topikal. Karena bentuknya yang praktis dan dalam penggunaanya sangat mudah sehingga banyak di gemari oleh masyarakat Indonesia khusunya kaum wanita dalam penggunaan kosmetik. (Partogi, 2008; Fatmawati 2015).

Pada Pembuatan krim yang harus diperhatikan adalah uji evaluasi sediaan, Evaluasi sediaan krim adalah parameter yang telah ditetapkan untuk mengetahui kestabilan sediaan krim diantaranya uji organoleptik, uji homogenitas, uji $\mathrm{pH}$, uji tipe krim, uji viskositas dan uji Daya sebar (Karmilah \& Musdalipah, 2018). Penelitian dalam metode studi literature masih banyak digunakan karena studi literatur memberikan manfaat untuk meningkatkan kepekaan teoritik penelitian untuk mengenali hasilhasil dari penelitian terdahulu yang terbaik dan sesuai dengan ketentuan yang telah di tetapkan (Afianti, 2005).

Dalam penelitian studi literatur dengan melihat hasil evaluasi sediaan krim yang masih jarang digunakan karena jenis pustaka tentang ilmu kefarmasian sudah cukup banyak tentang krim serta masih sedikit yang mengkaji mana formulasi yang paling maksimal dan efektif dari sekian banyak evaluasi sediaan krim, maka dari itu penulis memilih meneliti dengan penelitian literatur pada evaluasi krim adalah untuk membandingkan hasil-hasil evaluasi sediaan krim dari penelitian-penelitian sebelumnya agar mendapatkan hasil uji yang terbaik dan sesuai dengan ketentuan yang telah ditetapkan. Baik dari segi waktu, tenaga dan biaya penelitian dengan studi literatur ini lebih mudah, murah dan tidak memakan waktu yang begitu lama dalam proses penelitiannya 


\section{METODE}

Metode yang digunakan dalam penelitian review ini adalah metode penelitian komparatif dengan mengumpulkan berbagai sumber yang didapat dari beberapa jurnal penelitian yang berasal dari internet seperti Google scholar, Onesearch, Risetdikti, ResearchGatae dan sebagainya yang dipublish dari kurun waktu setidaknya 10 tahun terakhir. Dengan jenis penelitian kualitatif yang bersifat studi pustaka (library research) yang menggunakan buku-buku dan literaturliteratur lainnya sebagai objek yang utama (Zed, 2014). Penelitian studi literatur yang bersifat kualitatif yaitu dengan menempatkan hasil-hasil temuan terdahulu dalam konteks temuan yang baru saja ditemukan tetapi bukan berarti melakukan konfirmasi secara mendalam terhadap penelitian terdahulu.

\section{HASIL}

Berikut ini adalah hasil telaah dari sumber data review yaitu diketahui literatur penelitianya sebagai berikut :

1. Formulasi krim pemutih dari fiosom ekstrak daun murbei (Morus alba L) oleh Radia Rizki et al,. 2017.

2. Formulasi Dan Uji Stabilitas Krim Kombinasi Alfa Tokoferol Asetat Dan Etil Vitamin C Sebagai
Pelembab Kulit oleh Ratih Aryani 2015.

3. Formulasi dan Uji Stabilitas Fisik Sediaan Krim Ekstrak Etanol Kulit Buah Pisang Goroho (Musa acuminafe L.) Konsentrasi $12.5 \%$ Sebagai Tabir Surya" oleh Natalia Lumetuta et al,. 2020.

4. Formulasi Dan Evaluasi Krim Liofilisat Buah Tomat (Solanum Lycopersicum L) Sebagai Peningkat Kelembaban Pada Kulit oleh Nurul Arfiyanti Yusuf et al,. 2018.

5. Formulasi Sediaan Krim Antioksidan Ekstrak Etanolik Daun Alpukat (Persea americana Mill.) oleh Dina Mailana et al,. 2016.

6. Uji Stabilitas Fisik Formulasi krim yang mengandung ekstrak kacang kedelai (Glycine Max)" oleh Rosmala Dewi et al,. 2014.

7. Formuasi Krim Anti Jerawat Ekstrak Ampas Teh Hijau oleh Karmilah \& Musdalipah 2018.

8. Uji Stabilitas Krim Antioksidan Ekstrak Etanol 70\% dari biji melinjo (Gnetum gnemon L)" oleh Rabima dan Marshall 2017.

9. Uji Stabilitas Fisik Dan Kimia Sediaan Krim Ekstrak Etanol Tumbuhan Paku (Nepheropis 
Falcava (Cav) C. Chr)" oleh Putri

Wulandari 2016.

10. Formulasi Dan Uji Stabilitas Fisik

Sediaan Krim Anti Inflamasi
Ekstrak Etanol 70\% Herba Kumis

Kucing (Orthosiphone stamineus

Benth.) oleh Risa Natasya Andriani

2016.

Tabel 1 Hasil Review keseluruhan Jurnal

\begin{tabular}{|c|c|c|c|c|c|}
\hline No & Uji evaluasi & $\begin{array}{c}\text { Jumlah } \\
\text { jurnal }\end{array}$ & Materi Jurnal & Hasil Review & $\begin{array}{c}\text { Kesimpulan } \\
\text { Review }\end{array}$ \\
\hline 1. & $\begin{array}{c}\text { Uji } \\
\text { Organoleptis }\end{array}$ & 10 & $\begin{array}{l}\text { Uji evaluasi } \\
\text { organoleptis } \\
\text { bertujuan untuk } \\
\text { mengamati } \\
\text { warna, bau dan } \\
\text { tekstur pada } \\
\text { sediaan krim, uji } \\
\text { organoleptis akan } \\
\text { berpengaruh } \\
\text { terhadap } \\
\text { kenyamanan } \\
\text { pengguna oleh } \\
\text { karena itu } \\
\text { sebaiknya } \\
\text { sediaan memiliki } \\
\text { warna yang } \\
\text { menarik. Dari } \\
\text { beberapa jurnal } \\
\text { penelitian yang di } \\
\text { review jurnal } \\
\text { dibedakan pada } \\
\text { perbedaan } \\
\text { formulasi dengan } \\
\text { perbedaan } \\
\text { konsentrasi zat } \\
\text { aktif bahan alam } \\
\text { dan sintetis, } \\
\text { sehingga } \\
\text { berpengaruh pada } \\
\text { hasil uji } \\
\text { organoleptis. }\end{array}$ & $\begin{array}{l}\text { Metode : secara } \\
\text { keseluruhan jurnal, } \\
\text { metode yang } \\
\text { digunakan pada uji } \\
\text { organoleptis ialah } \\
\text { dengan } \\
\text { menggunakan teknik } \\
\text { visual yaitu dengan } \\
\text { mengamati masing- } \\
\text { masing sifat fisik } \\
\text { sediaan krim } \\
\text { terhadap bentuk, bau } \\
\text { dan warna. } \\
\text { Hasil : Berdasarkan } \\
\text { uji terdapat } 7 \text { jurnal } \\
\text { yang mendapatkan } \\
\text { hasil organoleptis } \\
\text { yang baik, baik dari } \\
\text { segi bentuk, warna } \\
\text { dan bau. } 3 \text { jurnal } \\
\text { memiliki bentuk dan } \\
\text { bau yang baik akan } \\
\text { tetapi terdapat } \\
\text { perubahan } \\
\text { kepekatan pada } \\
\text { warna. }\end{array}$ & $\begin{array}{l}\text { Dari hasil Review } \\
\text { menunjukan } \\
\text { bahwa standar } \\
\text { organoleptiks } \\
\text { yang baik adalah } \\
\text { tidak adanya } \\
\text { perubahan pada } \\
\text { sediaan dalam } \\
\text { penyimpanan } \\
\text { beberapa minggu, } \\
\text { baik dalam suhu } \\
\text { kamar, maupun } \\
\text { suhu rendah. } \\
\text { Didapatkan } 7 \\
\text { jurnal yang } \\
\text { memiliki } \\
\text { kestabilan } \\
\text { organoleptis baik } \\
\text { dari bentuk, bau } \\
\text { dan warna. } 3 \\
\text { jurnal memiliki } \\
\text { bentuk dan bau } \\
\text { yang baik akan } \\
\text { tetapi terdapat } \\
\text { perubahan } \\
\text { kepekatan warna, } \\
\text { hal tersebut di } \\
\text { pengaruhi oleh } \\
\text { tingkat konsentrasi } \\
\text { ekstrak yang } \\
\text { digunakan pada } \\
\text { formulasi. }\end{array}$ \\
\hline 2. & $\begin{array}{c}\text { Uji } \\
\text { Homogenitas }\end{array}$ & 10 & $\begin{array}{l}\text { Uji homogenitas } \\
\text { bertujuan untuk } \\
\text { melihat tingkat }\end{array}$ & $\begin{array}{l}\text { Metode : pengujian } \\
\text { homogenitas } \\
\text { dilakukan dengan }\end{array}$ & $\begin{array}{l}\text { Dari hasil review } \\
\text { menunjukan } \\
\text { bahwa secara }\end{array}$ \\
\hline
\end{tabular}




\begin{tabular}{|c|c|c|c|c|c|}
\hline No & Uji evaluasi & $\begin{array}{c}\text { Jumlah } \\
\text { jurnal }\end{array}$ & Materi Jurnal & Hasil Review & $\begin{array}{c}\text { Kesimpulan } \\
\text { Review }\end{array}$ \\
\hline & & & $\begin{array}{l}\text { kehomogenan } \\
\text { suatu krim } \\
\text { dengan } \\
\text { mengamati } \\
\text { partikel-partkel } \\
\text { kasar pada } \\
\text { sediaan krim, jika } \\
\text { sediaan krim } \\
\text { telah homogen } \\
\text { maka } \\
\text { diasumsikan } \\
\text { kadar zat aktif } \\
\text { akan selalu sama } \\
\text { pada saat } \\
\text { pengambian. }\end{array}$ & $\begin{array}{l}\text { cara mengoleksan } \\
\text { sebagian krim yang } \\
\text { telah ditentukan } \\
\text { jumlah nya pada } \\
\text { kaca objek yang } \\
\text { kemudian } \\
\text { dikatupkan pada } \\
\text { kaca preparat, } \\
\text { setelah itu diamati } \\
\text { butiran-butiran kasar } \\
\text { yang terdapat pada } \\
\text { krim. } \\
\text { Hasil : Berdasarkan } \\
\text { uji secara } \\
\text { keseluruhan formula } \\
\text { dalam jurnal yg di } \\
\text { review menunjukan } \\
\text { susunan yang } \\
\text { homogen dengan } \\
\text { ditandai tidak } \\
\text { adanya butiran- } \\
\text { butiran kasar pada } \\
\text { krim. }\end{array}$ & $\begin{array}{l}\text { keseluruhan jurnal } \\
\text { yang telah di } \\
\text { telaah memiliki } \\
\text { sediaan yang } \\
\text { bersifat homogen, } \\
\text { artinya zat aktif } \\
\text { pada formula telah } \\
\text { tercampur secara } \\
\text { merata pada zat } \\
\text { tambahan yg } \\
\text { terdapat dalam } \\
\text { formulasi krim. }\end{array}$ \\
\hline 3. & Uji pH & 10 & $\begin{array}{l}\text { Uji pH bertujuan } \\
\text { untuk } \\
\text { mengetahui } \\
\text { apakah sediaan } \\
\text { krim yang di buat } \\
\text { sudah sesuai } \\
\text { dengan pH krim } \\
\text { kulit atau tidak, } \\
\text { sediaan krim } \\
\text { harus mempunyai } \\
\text { nilai pH kulit } \\
\text { sesuai ketentuan } \\
\text { SNI 16-4399- } \\
\text { 1996 yaitu nilai } \\
\text { pH berkisar 4,5- } \\
\text { 8. Sehingga tidak } \\
\text { menyebabkan } \\
\text { iritasi pada kulit. }\end{array}$ & $\begin{array}{l}\text { Metode : Dalam } \\
\text { jurnal yang di } \\
\text { review terdapat } 2 \\
\text { alat dalam pengujian } \\
\text { yaitu alat pH meter } \\
\text { dan pH strip, cara } \\
\text { uji meggunakan alat } \\
\text { pH meter yaitu pH } \\
\text { meter dikalibrasi } \\
\text { dengan larutan } \\
\text { standar buffer pH } \\
\text { yaitu } 4 \text { dan } 7 \text {, } \\
\text { kemudian pH } \\
\text { dimasukan pada } \\
\text { gelas yang telah disi } \\
\text { dengan sediaan } \\
\text { krim, kemudian } \\
\text { hasil nilai keluar } \\
\text { dari pH meter } \\
\text { menunjukan nilai } \\
\text { pH sediaan. } \\
\text { Sedangkan cara uji }\end{array}$ & $\begin{array}{l}\text { Dari hasil review } \\
\text { menunjukan } \\
\text { bahwa nilai pH } \\
\text { pada semua } \\
\text { formulasi yang } \\
\text { telah di tlaah } \\
\text { memenuhi standar } \\
\text { mutu yang telah } \\
\text { ditetapkan yaitu } \\
\text { memenuhi syarat } \\
\text { Standar Nasional } \\
\text { Indonesia (SNI) } \\
\text { 16-4399-1996 } \\
\text { dengan batas } \\
\text { range 4,5-8,0. } \\
\text { Apabila pH terlalu } \\
\text { asam akan } \\
\text { mengakibatkan } \\
\text { kulit iritasi, dan }\end{array}$ \\
\hline
\end{tabular}




\begin{tabular}{|c|c|c|c|c|c|}
\hline No & Uji evaluasi & $\begin{array}{c}\text { Jumlah } \\
\text { jurnal }\end{array}$ & Materi Jurnal & Hasil Review & $\begin{array}{c}\text { Kesimpulan } \\
\text { Review }\end{array}$ \\
\hline & & & & $\begin{array}{l}\text { menggunakan pH } \\
\text { strip yaitu dengan } \\
\text { cara memasukan } \mathrm{pH} \\
\text { strip pada krim } \\
\text { kemudian pH strip } \\
\text { di cocokan dengan } \\
\text { warna acuan yang } \\
\text { tertera pada } \\
\text { kemasan indikator } \\
\text { pH strip. } \\
\text { Hasil : Berdasarkan } \\
\text { uji secara } \\
\text { keseluruhan } \\
\text { menunjukan bahwa } \\
\text { pH krim yang tertera } \\
\text { pada hasil penelitian } \\
\text { dari jurnal yg di } \\
\text { review memenuhi } \\
\text { syarat Standar } \\
\text { Nasional Indonesia } \\
\text { (SNI) 16-4399-1996 } \\
\text { dengan batas range } \\
\text { 4,5-8,0. Walaupun } \\
\text { ada yang mengalami } \\
\text { penurunan angka } \\
\text { tapi masih dalam } \\
\text { batas standar pH. }\end{array}$ & $\begin{array}{l}\text { apabila pH terlalu } \\
\text { basa akan } \\
\text { mengakibatkan } \\
\text { kulit bersisik. }\end{array}$ \\
\hline 4. & Uji Tipe krim & 10 & $\begin{array}{l}\text { Uji tipe krim } \\
\text { bertujuan untuk } \\
\text { mengamati tipe } \\
\text { krim pada } \\
\text { sediaan, uji ini } \\
\text { biasanya } \\
\text { menggunakan } 2 \\
\text { metode yaitu } \\
\text { metode } \\
\text { pengenceran dan } \\
\text { metode dispersi } \\
\text { warna, dalam } 10 \\
\text { jurnal yang } \\
\text { penulis tlaah } \\
\text { hanya } 4 \text { jurnal } \\
\text { yang melakukan } \\
\text { uji tipe krim, } \\
\text { tidak di sebutkan } \\
\text { mengapa jurnal }\end{array}$ & $\begin{array}{l}\text { Metode : seacara } \\
\text { keseluruhan jurnal } \\
\text { yang melakukan uji } \\
\text { tipe krim } \\
\text { menggunakan } \\
\text { metode } \\
\text { pengenceran, yaitu } \\
\text { dengan cara krim } \\
\text { yang telah dibuat } \\
\text { dimasukkan } \\
\text { kedalam gelas kimia } \\
\text { kemudian } \\
\text { diencerkan dengan } \\
\text { aquadest, jika } \\
\text { emulsi tidak } \\
\text { tercampurkan } \\
\text { dengan air maka } \\
\text { emulsinya tipe A/M, } \\
\text { begitupun }\end{array}$ & $\begin{array}{l}\text { Dari hasil review } \\
\text { menunjukan } \\
\text { bahwa secara } \\
\text { keseluruhan } \\
\text { pengujian tipe } \\
\text { krim } \\
\text { menggunakan } \\
\text { metode } \\
\text { pengenceran dan } \\
\text { hasil uji } 3 \text { krim } \\
\text { memiliki tipe M/A } \\
\text { dan } 1 \text { uji krim } \\
\text { memilik tipe } \mathrm{A} / \mathrm{M} .\end{array}$ \\
\hline
\end{tabular}




\begin{tabular}{|c|c|c|c|c|}
\hline No Uji evaluasi & $\begin{array}{c}\text { Jumlah } \\
\text { jurnal }\end{array}$ & Materi Jurnal & Hasil Review & $\begin{array}{c}\text { Kesimpulan } \\
\text { Review }\end{array}$ \\
\hline & & $\begin{array}{l}\text { yang lain tidak } \\
\text { melakukan uji } \\
\text { tipe krim. }\end{array}$ & $\begin{array}{l}\text { sebaliknya. } \\
\text { Hasil : berdasarkan } \\
\text { uji dari } 4 \text { jurnal } \\
\text { yang melakukan uji } \\
3 \text { jurnal memiliki } \\
\text { tipe krim M/A dan } 1 \\
\text { jurnal memiliki tipe } \\
\text { krim A/M. }\end{array}$ & \\
\hline
\end{tabular}

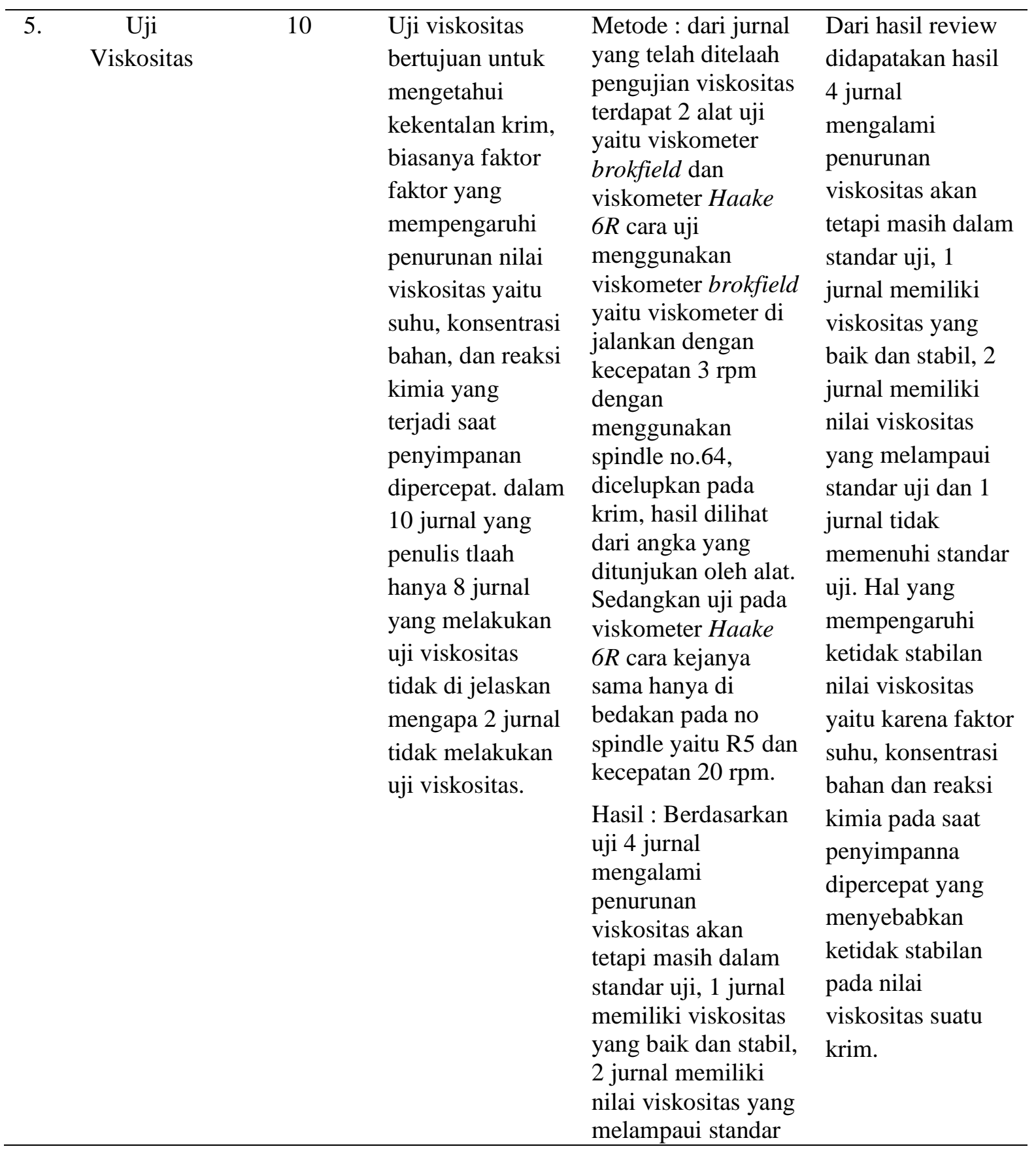




\begin{tabular}{|c|c|c|c|c|c|}
\hline No & Uji evaluasi & $\begin{array}{c}\text { Jumlah } \\
\text { jurnal }\end{array}$ & Materi Jurnal & Hasil Review & $\begin{array}{c}\text { Kesimpulan } \\
\text { Review }\end{array}$ \\
\hline & & & & $\begin{array}{l}\text { uji dan } 1 \text { jurnal tidak } \\
\text { memenuhi standar } \\
\text { uji. Sehingga yang } \\
\text { tidak memenuhi } \\
\text { standar uji adalah } 4 .\end{array}$ & \\
\hline 6. & $\begin{array}{l}\text { Uji Daya } \\
\text { sebar }\end{array}$ & 10 & $\begin{array}{l}\text { Uji daya sebar } \\
\text { bertujuan untuk } \\
\text { mengetahui } \\
\text { kemampuan } \\
\text { penyebaran krim } \\
\text { didalam kulit, } \\
\text { krim yang baik } \\
\text { memiliki daya } \\
\text { sebar yang besar } \\
\text { sehingga tidak } \\
\text { perlu penekanan } \\
\text { pada kulit. dalam } \\
10 \text { jurnal yang } \\
\text { penulis tlaah } \\
\text { hanya } 7 \text { jurnal } \\
\text { yang melakukan } \\
\text { uji daya sebar, } \\
\text { tidak dijelaskan } \\
\text { mengapa } 3 \text { jurnal } \\
\text { tidak melakukan } \\
\text { uji daya sebar. }\end{array}$ & $\begin{array}{l}\text { Metode : secara } \\
\text { keseluruhan jurnal, } \\
\text { uji daya sebar } \\
\text { dilakukan dengan } \\
\text { cara krim sebanyak } \\
0,5 \text { gram diletakan } \\
\text { pada lempengan } \\
\text { kaca arloji, atau } \\
\text { kaca objek dan } \\
\text { cawan petri yang } \\
\text { dilapisi kertas } \\
\text { grafik, kemudian } \\
\text { diberi beban pada } \\
\text { kaca arloji atau kaca } \\
\text { objek dan cawan } \\
\text { petri selama } 1 \text { menit } \\
\text { dengan beban } 50 \text { gr, } \\
100 \text { gr dan } 200 \text { gr } \\
\text { kemudian diukur } \\
\text { rata-rata diameter } \\
\text { nya dari beberapa } \\
\text { sisi. } \\
\text { Hasil : Berdasarkan } \\
\text { Uji } 4 \text { jurnal yang } \\
\text { memiliki daya sebar } \\
\text { yang baik, } 2 \text { jurnal } \\
\text { tidak memenuhi } \\
\text { standar karena } \\
\text { kurang dari batas } \\
\text { standar uji dan } 1 \\
\text { jurnal melebihi batas } \\
\text { standar daya sebar } \\
\text { krim. sehingga dapat } \\
\text { diatakan yang tidak } \\
\text { memenuhi standar } \\
\text { uji adalah } 3 .\end{array}$ & $\begin{array}{l}\text { Standar uji daya } \\
\text { sebar menurut SNI } \\
1996 \text { yaitu nilai } \\
\text { daya sebar } \\
\text { memiliki nilai } \\
\text { range (5-7 cm). } \\
\text { Dari hasil review } \\
\text { di dapatakan hasil } \\
\text { terdapat } 4 \text { jurnal } \\
\text { yang memiliki } \\
\text { daya sebar yang } \\
\text { baik, } 2 \text { jurnal tidak } \\
\text { memenuhi karena } \\
\text { kurang dari } \\
\text { standar uji dan } 1 \\
\text { jurnal melebihi } \\
\text { batas standar daya } \\
\text { sebar krim. hal } \\
\text { yang } \\
\text { menyebabkan nilai } \\
\text { daya sebar krim } \\
\text { tidak sesuai } \\
\text { standar yaitu } \\
\text { dikarnakan } \\
\text { konsentrasi } \\
\text { ekstrak yang di } \\
\text { tambahakan } \\
\text { semakin besar } \\
\text { kadar ekstrak akan } \\
\text { semakin pekat dan } \\
\text { berpengaruh pada } \\
\text { penurunan daya } \\
\text { sebar krim dan di } \\
\text { pengaruhi oleh } \\
\text { nilai viskositas } \\
\text { suatu krim, karena } \\
\text { semakin besar } \\
\text { viskositas, nilai } \\
\text { daya sebar }\end{array}$ \\
\hline
\end{tabular}




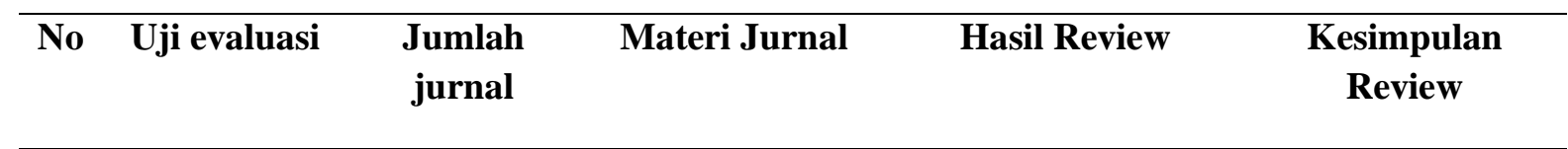

semakin menurun.

\section{PEMBAHASAN}

Dari jurnal yang di review terdapat 2 kelompok formulasi dengan perbedaan tingkat konsentrasi bahan alam dan bahan sintetis, uji evaluasi pada sediaan krim bertujuan agar sediaan krim yang dibuat memenuhi standar uji yang telah di tetapkan. secara keseluruhan jurnal, tidak semua jurnal melakukan uji evaluasi yang tertera diatas seperti uji viskositas, daya sebar, $\mathrm{pH}$, tipe krim homogenitas dan organoletis. Terdapat beberapa jurnal yang tidak melakukan beberapa uji evaluasi diatas, di dalam jurnal tidak jelaskan mengapa tidak melakukan uji evaluasi tersebut.

Standar Uji organoleptiks dikatakan stabil jika bentuk, bau dan warna tidak mengalami perubahan setelah dilakukan penyimpanan dipercepat, Uji homogenitas dikatakan homogen jika sediaan krim tidak terdapat partikel atau butiran kasar pada sediaan krim, Standar uji pH menurut SNI 16-4399-1996 dengan batas range 4,5-8,0. Standar uji Viskositas menurut SNI 164339-1996 yaitu dengan batas range 200050.000 cps dan Satndar uji Daya sebar menurut SNI 1996 yaitu nilai daya sebar dalam batas range $(5-7 \mathrm{~cm})$.
Dari kesepuluh jurnal yang direview di dapatkan hasil untuk uji organoleptiks, 7 jurnal memenuhi standar uji 3 jurnal tidak memenuhi standar uji, uji homogenitas 10 jurnal memilki homogenitas yang baik, uji tipe krim 4 jurnal melakukan uji tipe krim, 6 jurnal tidak melakukan uji untuk hasil nya 3 jurnal memiliki tipe krim M/A dan 1 jurnal A/M, uji pH 10 jurnal memenuhi standar uji $\mathrm{pH}$, uji viskositas 5 jurnal memenuhi standar uji, 3 jurnal tidak memenuhi standar uji dan untuk uji daya sebar 4 jurnal memenuhi standar uji dan 3 jurnal tidak memenuhi standar uji.

Hal yang meyebabkan ketidak stabilan uji evauasi sediaan krim adalah untuk uji organoleptiks yaitu disebabkan oleh nilai konsentrasi ekstrak yang digunakan pada formula masing-masing jurnal, uji homogenitas yaitu ketidak tercapur secara merata bahan yang di gunakana pada saat pembuatan krim, uji tipe krim dilakukan dengan menggunakan teknik pengenceran dengan cara melarutkan krim pada air jika krim larut secara keseluruhan pada air maka krim bersifat M/A begitupun sebaliknya ,untuk uji $\mathrm{pH}$ biasanya disebabkan oleh reaksi kimia dan faktor 
suhu pada saat penyimpanan dipercepa, uji viskositas hal yang menyebabkan ketidak stabilan nilai viskositas yaitu pengaruh suhu dan tingkat konsentrasi zat aktif serta emulgator yang terlalu besar sehingga mempengaruhi nilai viskositas, karena suhu tinggi pada saat penyimpanan dipercepat menyebabkan krim tersebut menjadi lebih encer stabilitas krim akan menjadi rusak jika terjadi perubahan suhu dan konsentrasi berlebih, dan untuk uji daya sebar hal yang mempengaruhi ketidak stabilan uji daya sebar yaitu dikarnakan konsentrasi ekstrak yang di tambahakan semakin besar kadar ekstrak akan semakin pekat dan berpengaruh pada penurunan daya sebar krim, serta di pengaruhi oleh nilai viskositas suatu krim sehingga ketidak stabilan daya sebar pada krim akan menyebabkan ketidak nyamanan pada saat diapliasikan pada kulit.

\section{KESIMPULAN}

Hasil review dari kesepuluh jurnal di dapatkan hasi uji organolpetiks yaitu 7 jurnal memiliki uji organoleptis yang baik dan 3 memiliki perbedaan di tiap warna krim, hal tersebut disebabkan faktor konsentrasi ekstrak yg berlebih pada krim sehingga mempengaruhi warna krim, pada uji tipe krim yaitu dengan menggunakan metode pengenceran karena pengujianya lebih mudah dan praktis dari metode dispersi warna. Dari hasil penelitian di dapatkan krim dengan tipe krim 3 jurnal memiliki M/A dan 1 jurnal $\mathrm{A} / \mathrm{M}$, uji homogenitas secara keseluruhan dalam jurnal yg di review krim memiliki tingkat homogenitas yang cukup baik tidak terdapat partikel kasar pada krim yg telah di telaah, menandakan bahwa sediaan krim bersifat homogen, uji $\mathrm{pH}$ secara keseluruhan dalam jurnal yg di review, krim memiliki nilai $\mathrm{pH}$ yang baik dan memenuhi standar $\mathrm{pH}$, yang mempengaruhi ketidak stabilan nilai $\mathrm{pH}$ yaitu dipengaruhi oleh reaksi kimia dan faktor suhu pada saaat penyimpanan dipercepat, uji viskositas didapatkan hasil 4 jurnal mengalami penurunan viskositas akan tetapi masih dalam standar uji, 1 jurnal memiliki viskositas yang baik dan stabil, 2 jurnal memiliki nilai viskositas yang melampaui standar uji dan 1 jurnal tidak memenuhi standar uji. Hal tersebut dipengaruhi oleh faktor suhu dan dan reaksi kimia pada saat penyimpanan dipercepat dan untuk uji daya sebar di dapatkan hasil 4 jurnal memiliki daya sebar yang baik, 2 jurnal tidak memenuhi di karenakan kurang dari nilai standar uji dan 1 jurnal melebihi batas standar uji daya sebar krim akan tetapi terdapat beberapa uji yang tidak memenuhi standar uji dikarenakan pengaruh faktor konsentrasi ekstrak yg digunakan dan suhu pada saat penyimpanan dipercepat 


\section{DAFTAR PUSTAKA}

Afiyanti yati. (2013). "Penggunaan literatur dalam penelitian Kualitatif “. Jurnal keperawatan Indonesia Vol.9, No 1 (h.32-35). pISSN1410-4490 eISSN23549203 Jki.ui.ac.id

Andriani Risa Natasya. (2016). Formulasi dan uji stabilitas fisik sediaan krim anti inflamasi Ekstrak etanol $70 \%$ herba kumis kucing (Orthosiphone stamineus Benth.). Skripsi UIN Syarif Hidayatullah Jakarta.

Aryani Ratih, (2015). "Formulasi Dan Uji Stabilitas Krim Kombinasi Alfa Tokoferol Asetat Dan Etil Vitamin C Sebagai Pelembab Kulit”. Jurnal Kesehatan Bakti tunas husada vol 14. No.1. ( h.38-46).

Dewi Rosmala et al,.(2014). "Uji Stabilitas Fisik Formulasi krim yang mengandung ekstrak kacang kedelai (Glycine Max)". Pharm Sci Res ISSN 2407-2354 Vol. 1 No. 3 (h.194-208).

Ditjen POM. 2014. Farmakope Indonesia Edisi $V$, h. 51. Jakarta: Kementrian Kesehatan RI.

Fatmawati.A., Nisa.M., \& Rhadia Riski. 2015. Teknologi Sediaan Farmasi. Yogyakarta: deepublish.

Lumetuta Natalia et al,. (2020). Formulasi dan Uji Stabilitas Fisik Sediaan Krim Ekstrak Etanol Kulit Buah Pisang Goroho (Musa acuminafe L) Konsentrasi $12.5 \%$ Sebagai Tabir Surya". Jurnal MIPA UNSRAT vol. 9. No.2. h. 42-46.

Mailana Dina et al,. (2016). "Formulasi Sediaan Krim Antioksidan Ekstrak Etanolik Daun Alpukat
(Persea americana Mill.)". ISSN: 2337-8433. Acta Pharmaciae Indonesia. Vol.4.no.4.h.7-15.

Marshall dan Rabima. (2017). "Uji stabilitas krim antioksidan ekstrak etanol $70 \%$ dari biji melinjo (Gnetum gnemon L)". Indonesia Natural Research Pharmaceutical. Journal Issn Online: 2502-8421. Vol.2.No.1.h.107-121.

Musdalipah \& Karmilah. (2018). Formuasi Krim anti jerawat ekstrak ampas teh hijau. Jurnal Insan Farmasi Indonesia. ISSN cetak 2621-3184 ISSN online 2621-4032 Vol.1.No.1.h. 26-33.

Rizki Rhadia et al,. (2017). "Formulasi krim pemutih dari fitosom ekstrak daun murbei (Morus alba $L)$ ". Jurnal farmasi FKIP UINAM vol 5. No.4.

Sharon N., Anam S., Y. (2013). Formulasi Krim Antioksidan Ekstrak Etanol Bawang Hutan (Eleutherine palmifolia L. Merr). Online Jurnal of Natural Science, Vol. 2 (No.3), h.111122.

Wulandari Putri. (2016). "Uji Stabilitas Fisik dan kimia sediaan krim Ekstrak etanol Tumbuhan paku (Nepheropis Falcava (Cav) C. Chr)". Skripsi UIN syarif Hidayatullah Jakarta.

Yusuf Arfiyanti Nurul et al,. (2018). Formulasi Dan Evaluasi Krim Liofilisat Buah Tomat (Solanum Lycopersicum L) Sebagai Peningkat Kelembaban Pada Kulit. Jurnal umbjm. Vol.2. No.1. (h.118-124). ISSN : 25982095. 
Literature Review Uji Evaluasi...

Zed, M. 2014. Metode Penelitian Kepustakaan. Jakarta: Yayasan Obor Indonesia. 

